\title{
Changes in gender wage discrimination in the 1990s: A tale of three very different economies
}

\author{
Geraint Johnes ${ }^{\mathrm{a}, *}$, Yasuhide Tanaka ${ }^{\mathrm{b}}$ \\ ${ }^{a}$ Lancaster University Management School, Lancaster LA1 4YX, United Kingdom \\ ${ }^{\mathrm{b}}$ Faculty of Economics, Kobe University, Rokko, Nada, Kobe 657-8501, Japan
}

Received 20 June 2005; received in revised form 5 July 2006; accepted 21 September 2006

\begin{abstract}
In this paper gender wage decompositions are performed for three very different countries, that is, Japan, Russia and the USA for the years of 1993 and 2000, using the ISSP data set. From the research of this paper, it is shown that the gender wage differential in Japan has narrowed between 1993 and 2000, and the results reveal price and characteristics effects for this country that differ markedly from those observed elsewhere, with female disadvantage being particularly marked. Also, this paper finds that gender wage differentials in Russia and the USA have increased during the years considered here.
\end{abstract}

(C) 2006 Elsevier B.V. All rights reserved.

JEL classification : J71; P52

Keywords: Gender; Discrimination; Japan; Russia; USA

\section{Introduction}

As markets go, the labour market is a curious one. It works, but it works imperfectly. Demand and supply interact, but institutions are important too. Hence the manner in which the labour market operates differs very markedly from country to country, and this gives rise to imperfections that are more pronounced in some countries than in others. This makes the labour market a fascinating subject of study, but it is also an important subject-for imperfections in the operation of the labour market have a very direct impact on people's lives and happiness. One of the manifestations of an imperfectly operating labour market is discrimination, and that forms the subject of the study reported in this paper.

* Corresponding author. Tel.: +44 1524 594215; fax: +44 1524594244.

E-mail addresses: G.Johnes@lancs.ac.uk (G. Johnes), tanaka@econ.kobe-u.ac.jp (Y. Tanaka). 
Discrimination is a phenomenon that is only very imperfectly understood by economists. Becker (1957) provides an early model that allows us to understand what the effects of discrimination might be, given that an employer discriminates. More recent models have attempted to explain why gender discrimination might exist in the first place. A particularly influential paper has been that of Lazear and Rosen (1990) which argues that women have higher rates of turnover (owing to their comparative advantage in household production), and that therefore firms are relatively unwilling to promote women since this entails a training cost that might not be recouped; the relatively low incidence of promotion for women results in a gender earnings differential. While appealing in many respects, this model has received only partial empirical support (Booth et al., 2003).

The empirical measurement of discrimination is much more well developed. The decomposition approach developed by Oaxaca (1973) is standard. This allows the wage differential between men and women to be split into components that measure, respectively, that part of the differential that is due to differences in the characteristics of the typical male and the typical female, and that part that is due to (what may be unjustified) differences across genders in the rewards that are attached to those characteristics. It is a variant of this approach that we shall pursue in the sequel.

Since the institutions that interfere with the adjustment of the labour market differ from one jurisdiction to another, it is instructive to compare experience of discrimination across countries. In this paper, we study gender discrimination in three very different countries, using a single source of data. We perform the comparison across 2 years, 1993 and 2000, in order to evaluate the extent to which the labour market in these three economies has been changing over the recent past. ${ }^{1}$ The countries investigated are the USA (a relatively free market), Japan (a market with relatively free adjustment of wages, but with strong labour market institutions), and Russia (a large economy that has been in transition over the study period).

The structure of the remainder of the paper is as follows. In the next section, we review the relevant literature. There follows a section on the data source and the methodology that is used in the empirical work. The results of this empirical analysis are reported and discussed at length in the following section, before conclusions are drawn and suggestions for future research are offered.

\section{Received literature}

The literature on labour market discrimination is vast. The statistical approach that has now become standard is to estimate separate wage equations for each group, and then to construct a decomposition of the wage differential. This allows identification of those parts of the wage gap that are due to differences in characteristics themselves, on the one hand, and the return to characteristics, on the other. It is readily observed that this emphasis on wage determination as a function of worker characteristics fits neatly into a human capital model of wage determination.

Since the emphasis of the current paper is focused specifically on the labour market within three economies, the remainder of this section will be devoted to a brief survey of the literature that relates to these countries. We begin by considering the literature on wage discrimination in Japan.

\footnotetext{
${ }^{1}$ These are the earliest and most recent years, respectively, for which complete data on the variables used in the study are available.
} 
It has often been noted that the Japanese labour market is different from ones of the USA and the European countries. The lifetime employment system and the wage structure represented by substantial profit-related remuneration arrangements are the most familiar characteristics of the Japanese labour market among economists and some economists have connected the economic performances in Japan with such labour-market institutions (see, for example, Gordon, 1982; Hashimoto, 1990). However, the characteristics of the Japanese labour market denoted above are mainly concentrated in large firms, and so the main beneficiaries of the unique system are regular male workers, since there is a concentration of such workers in the large firms. This might explain, in part at least, another characteristic of the Japanese labour market: Japan's malefemale wage differentials are extremely high compared to other developed countries (see Mincer, 1985; ILO, 1992; Blau and Kahn, 1995). Hence, while the gender differential is between 35 and 40 percent in both the US and Russia, a differential of some 85 percent is noted by Blau and Kahn (2003) for Japan. ${ }^{2}$ Therefore, the male-female wage differential has been an important subject of study in Japan for some time now, and there has been much empirical literature focusing on this aspect of the labour market.

Based on empirical studies, there are two main factors that underpin male-female wage differentials. The first factor is based on differences in characteristics between male and female workers, namely, age, years of experience, duration of work, years of schooling (educational attainment), firm size, etc. The second factor is based on how the firm evaluates these characteristics, that is, the return to characteristics.

The empirical study of Japan's male-female wage differentials based on the decomposition approach by Blinder (1973) and Oaxaca (1973) was first undertaken by Yashiro (1980). In this study, it was detected that 56.4 percent of male-female wage differentials in Japan was due to the effects of differences in characteristics, 34.3 percent, due to discriminating factors, while the remaining 9.3 percent was explained by limiting the workers in the study into regular workers. After this study, some empirical studies have been done by using the Blinder-Oaxaca type of decomposition and by applying it to extended data sets. For example, Tanaka (2002) has used the new decomposition method by Oaxaca and Ransom (1994) using data from the Basic Survey on Wage Structure publicly published and has found the empirical results that about 80 percent of male-female wage differentials can be explained by the differences in characteristics and the remaining percentages are attributed to the discrimination factor. However, these results of the previous studies have been found by using data in aggregated form. In this paper, therefore, we will use micro data, the ISSP data, in order to consider the Japanese gender wage differentials and to compare these with other countries by using same data set. ${ }^{3}$

In Russia, the labour market has experienced considerable turbulence in the wake of the transition to a more market oriented economy. Output fell dramatically in the early 1990s as competition intensified and the guaranteed markets of the past evaporated. Hence, for example, in 1992 alone, the decline in GDP amounted to some 15 percent, and by the year 2000, GDP was (while growing) still some 19 percent below its 1992 value. As economic growth was restored later in the decade, the structure of industry changed dramatically, with sectors such as

\footnotetext{
${ }^{2}$ While Blau and Kahn (2003) have indicated 85 percent as the Japanese gender differential, it seems quite large. It may be a result that they have evaluated at $40 \mathrm{~h}$ work. In this paper, therefore, we will re-examine the gender pay differentials by using same data set different from the periods considered as one by their paper.

${ }^{3}$ While Blau and Kahn (2003) have used the ISSP data to consider the international differences in the gender pay gap, they have used the data of 1985-1994 and they did not consider Russia explicitly. In this paper, we will consider the gender pay gap of three very different economies including Russia during the 1990s.
} 
metallurgy expanding rapidly while others - engineering and much light industry, for example remained in decline. This industrial shift had clear implications for the labour market. The pattern of skills that are in high demand is different from the corresponding pattern in the early years of the transition.

With the expansion of the private sector, and the influx of multinational enterprises, the labour market in Russia became increasingly competitive-though large pockets remain that are dominated by institutions and regulation. To a degree that would be unusual in more stable settings, workers with high levels of general human capital might be expected to change occupations, responding to wage signals that have been especially pronounced (Berger et al., 2001), though it should be noted that the empirical evidence on this is ambiguous.

Under the Soviet system a higher proportion of women worked than was then common in the West. This was largely a response to an economic imperative; with a regime of fixed wages and prices, meeting basic human needs required an income that could not be met by just one of a couple (Newell and Reilly, 1996, 2001). Women enjoyed substantial rights at the workplace, but occupational segregation on the basis of gender remained a pronounced feature of the labour market. Consequently, in spite of the high levels of female participation in the labour force, a wage differential in favour of men existed.

This differential remains in the period since the transition began. A number of studies of the gender pay gap in post-Soviet Russia have been conducted, notably those of Newell and Reilly (1996, 2001), Oglobin (1999) and Glinskaya and Mroz (2000). These studies have exploited new data sources such as the Russian Longitudinal Monitoring Survey. The main findings of these studies suggest that the gender wage gap in Russia is comparable to that observed in many Western economies (though less than in these economies prior to the introduction of equal pay legislation). Of the total differential, Oglobin finds that none is accounted for by differences in the characteristics of the average man and average woman - in other words, the entire wage gap is due to differences in the prices that these characteristics pay for men and women, respectively. ${ }^{4}$ Likewise, Glinskaya and Mroz find that characteristics play no part in explaining the gender earnings gap in Russia, and that much of the earnings gap is due to differences in hours worked. This provides an interesting point of comparison with results that we report in the sequel, where we use the hourly wage as the measure of remuneration. ${ }^{5}$

The labour market in the USA is widely regarded as being amongst the most flexible in the world. While institutions such as unions exist, 'right to work' laws curtail their influence in many states. Episodes of high unemployment rates tend to be short lived, as wages adjust reasonably rapidly. Yet discrimination along gender lines is as endemic here as elsewhere.

Early studies by, inter alia, Blau and Ferber (1987) established that the wage gap between men and women in the USA has typically amounted to between 30 and 40 percent, and has been toward the bottom end of this range in the most recent years. Of this, most remains unjustified by

\footnotetext{
${ }^{4}$ Ogoblin also estimates a model augmented by industry and occupation dummies; in this case, characteristics (which may here be interpreted as occupational and industrial segregation) account for about two thirds of the wage gap. Blau and Ferber (1987) provide a good discussion of whether or not such dummies have a place in the wage equation. While their inclusion raises the proportion of the wage differential that can be explained or 'justified', their significance is likely due to occupational segregation that is in itself discriminatory. We do not therefore include them in the analysis reported in the sequel.

${ }^{5}$ In the Russian context, the situation is compounded by the emergence of a wide pay differential between the private and public sectors (Jovanovic and Lokshin, 2004), though our data do not allow us to analyse this in the empirical work that follows.
} 
differences in the mean attributes of men and women. The availability of a rich source of panel data in the USA (in the form of the Panel Study of Income Dynamics) has allowed several researchers to model unobserved heterogeneity in characteristics. An early example is the work of Polachek and Kim (1994), though further work by Blau and Kahn $(1996,1997)$ has also pursued a similar path. These studies find that unobserved characteristics explain about as much of the gender wage gap as do observed characteristics. Notwithstanding this, the unjustified component of the wage differential (that part that is due to differences in the prices of characteristics) has increased over time. So while women have benefited from an improved vector of characteristics and from changes in the income distribution, they have nonetheless been 'swimming upstream'.

One aim of comparative studies of the kind undertaken in the present paper is to evaluate the extent to which institutional arrangements affect outcomes. While results reported below are certainly suggestive and can lead us to speculate about the impact that institutions might have, a comparative statistical analysis of three countries is not adequate for this task. For what it is worth, our results are consistent with an interpretation that (some) institutions can exacerbate discrimination; but equally it is clear from the literature that other institutions (such as equal pay legislation) can reduce it. While more work is needed on the impact that institutions can have on labour market discrimination, such work should entail more detailed analysis of institutions than is possible from a statistical cross-section study of countries.

\section{Data and methodology}

The data used in the present study come from the International Social Survey Programme (ISSP) 1993 and 2000 waves. The ISSP is an internationally coordinated series of annual surveys that has been running since 1985, when six countries (Australia, Austria, Germany, Italy, the United Kingdom and the USA) took part. By the year 2000, some 25 nations were participating in the surveys. Typically the surveys are run alongside pre-existing official surveys conducted within each country by the various statistical authorities. Hence, for example, in the USA, the ISSP is conducted alongside the General Social Survey. The definitions of variables used in each country are standardised ensuring direct comparability of the data across countries, this providing motivation for using the ISSP in the Russian and American contexts despite the fact that larger datasets exist in these countries.

Each year, the ISSP obtains demographic, labour market, and social information about respondents. Furthermore, in each year, a special topic is examined, and on these topics a variety of detailed questions are asked. In terms of numbers of respondents, the surveys are medium scale, the most usual sample size generally being 1000-2000 within each country.

In the context of the present study, the ISSP is of immense value. Microdata are readily available for the USA and many other countries (from, for instance, the Current Population Survey), and these have been extensively analysed in the received literature. The data sets used in such studies are usually much larger than the ISSP. However, individual level data are not so easily available for the other countries studied here. In the case of Japan, the popular wage data are the Basic Survey on Wage Structure and those data are collected and publicly published as cell means by the Ministry of Health, Labour and Welfare. Therefore, the present study represents an attempt to analyse male-female wage differentials in Japan using the same microdata techniques as have been in widespread use in other countries. In Russia, some analysis of wage functions has been conducted using the Russian Longitudinal Monitoring Survey (see, for example, Newell and Reilly, 1999); this is a survey of about 6000 households and reports data 
on a variety of economic and social variables. By virtue of the fact that the ISSP surveys are internationally coordinated, these surveys provide us with a unique opportunity to analyse several different countries while ensuring that the comparison takes place on as level a playing field as possible.

Previous analyses of ISSP data in the context of labour economics include analyses of labour relations in East European economies (Blanchflower and Freeman, 1997), an investigation of the impact of labour market institutions on economic outcomes (Bertola et al., 2003), the relationship between labour market institutions and the gender pay gap in international perspective (Blau and Kahn, 2003), and attempts to distinguish between human capital and sorting models of education (Johnes, 1998). ${ }^{6}$

In the present analysis, our aim is to evaluate the extent of labour market discrimination across genders in each of the three countries at two points in time. The countries - Japan, Russia and the USA - are chosen to be representative of three very different types of labour market, while the time periods - 1993 and 2000 - are chosen to provide an illustration of how the labour markets in each country have been developing during the 1990s. Also, we use the data of full-time workers of male and female whose ages are 15-60 years old. ${ }^{7}$ The reasons why we use such data are firstly that part-time workers might face a different wage-setting system from that facing full-time workers, and secondly that full-time workers over 60 years old have often retired from the their first job (in some of our countries at least) so that their pay structure might be different from the structure facing full-time workers under 60 years old. These reasons are especially applicable to the Japanese labour market.

The method of analysis is typical of discrimination studies. We estimate separate wage functions for males and females for each year in each country. These may be represented (omitting for convenience the error terms ${ }^{8}$ ) as:

$$
\ln W_{\mathrm{m}}=X_{\mathrm{m}}^{\prime} \hat{\beta}_{\mathrm{m}}
$$

and

$$
\ln W_{\mathrm{f}}=X_{\mathrm{f}}^{\prime} \hat{\beta}_{\mathrm{f}}
$$

respectively, where $W$ is the earnings per working hour and $X$ is a vector of explanatory variables. The hourly wage is calculated as weekly earnings divided by normal hours of work. While data for earnings are grouped, this process of calculating the hourly wage ensures that we use as regressor a variable that is (at least almost) continuous. We also estimate a pooled earnings equation:

$$
\ln W=X^{\prime} \beta^{*}
$$

The variables included in the vector, $X$, are chosen by reference to the human capital model developed by Schultz (1961) and Becker (1964), and given empirical substance by Mincer

\footnotetext{
${ }^{6}$ It should be noted that, while Blau and Kahn study issues similar to those considered here, they do not report countryspecific Oaxaca decompositions. Moreover, data for Russia and Japan used in their study are drawn from very short time intervals in the early 1990 s, so that our results represent a very significant update for these countries.

${ }^{7}$ We recognise that the statutory retirement age for women in Russia is 55, but note that many Russian women in our sample are earning wages (and so presumably are working) beyond this age.

${ }^{8}$ Since Oaxaca decompositions are evaluated at the means of all variables, this is standard procedure and has no impact on the analysis.
} 
(1974). Hence, education and potential experience (which is calculated by age minus total schooling years minus six for each worker) are key explanatory variables. ${ }^{9}$ We also include variables that indicate marital status and union membership, as well as a full set of regional dummy variables for each country.

At mean values of the explanatory variables (denoted in the sequel by a bar), the error term is zero. Using this, and following Oaxaca and Ransom (1994), the wage differential between men and women may be represented by the decomposition:

$$
\ln \left(G_{\mathrm{mf}}+1\right)=\ln W_{\mathrm{m}}-\ln W_{\mathrm{f}}=\bar{X}_{\mathrm{m}}^{\prime}\left(\hat{\beta}_{\mathrm{m}}-\beta^{*}\right)+\bar{X}_{\mathrm{f}}^{\prime}\left(\beta^{*}-\hat{\beta}_{\mathrm{f}}\right)+\left(\bar{X}_{\mathrm{m}}-\bar{X}_{\mathrm{f}}\right)^{\prime} \beta^{*}
$$

where $G_{\mathrm{mf}}=\left(W_{\mathrm{m}} / W_{\mathrm{f}}\right)-1$. The first term on the right hand side of Eq. (4) is an indicator of male advantage due to price effects (that is, due to differences in the coefficients, or 'prices' or values, attached to different characteristics), and the second term provides a measure of female disadvantage owing to price effects. The third term shows the characteristics effect. This is the portion of the wage differential that may be attributed to differences in the characteristics possessed by men and women.

In estimating wage equations of this type, an issue that has often been raised in the literature concerns sample selection effects. This is particularly pertinent in the estimation of wage functions for women, since the sample of women on which the wage function is estimated will often not be a random draw from the population. Owing to social norms women often face higher opportunity costs (in the form of household production) of labour market work than do men. Consequently, the sample of women that work in the labour market, and so are included in wage regressions, may be biased, with potential high earners being overrepresented. Heckman (1979) has provided one method whereby such biases can be corrected. This method has not been uncontroversial in the literature, however (Puhani, 2000), and the results that we report in the sequel are those obtained by ordinary least squares. ${ }^{10}$

Since we are estimating wage equations for two distinct time periods, it is interesting to consider also the more recently developed decompositions pioneered by Juhn et al. $(1991,1993)$. This begins with the observation that (4) may be rewritten as:

$$
\ln W_{\mathrm{m}}-\ln W_{\mathrm{f}}=\Delta X \beta_{\mathrm{m}}+\sigma_{\mathrm{m}} \Delta \theta
$$

where $\Delta$ represents the gender difference in the mean value of the variable that follows, $\theta$ the standardised residual and $\sigma$ is the standard deviation of the unstandardised residual. Comparison across years (here subscripted by 00 for the year 2000 and 93 for the year 1993) allows the change

\footnotetext{
${ }^{9}$ Potential experience must be used in the absence of data in the ISSP for actual experience. Other data sources would allow actual experience to be used in analyses of this kind for two of the countries studied here, but the non-availability of other data sources for Japan - and our desire to compare the Japanese results with those obtained for other countries compels us to use potential experience instead. This is, of course, a very commonly used and well understood measure in the literature. Note that, since potential experience provides an upwardly biased measure of (especially female) actual experience, adoption of this measure likely leads to an upwardly biased measure of discrimination.

${ }^{10}$ We have used Heckman's approach to estimate analogues of all the equations reported in the sequel, but found the inverse Mills ratio to be insignificant in all cases bar one (USA females in 2000). The participation probit included, as indentifying variable, household size. We note that the use of OLS rather than a Heckman approach is standard in studies of discrimination, since gender wage discrimination is conditional on women working.
} 
in the gender wage differential, $D$, to be decomposed as:

$$
\begin{aligned}
D_{93}-D_{00}= & \left(\Delta X_{93}-\Delta X_{00}\right) \hat{\beta}_{\mathrm{m} 00}+\Delta X_{93}\left(\hat{\beta}_{\mathrm{m} 93}-\hat{\beta}_{\mathrm{m} 00}\right)+\left(\Delta \theta_{93}-\Delta \theta_{00}\right) \sigma_{\mathrm{m} 00} \\
& +\Delta \theta_{93}\left(\sigma_{\mathrm{m} 93}-\sigma_{\mathrm{m} 00}\right)
\end{aligned}
$$

Here the first term on the right hand side captures the contribution made to closing the gender wage gap by changes in the observed human capital characteristics of men and women, respectively. The second term captures the impact of changes in the observed prices attached to each characteristic. The third term, often referred to in the literature as the 'gap', measures the impact of the movement of women through the male distribution of wages, holding constant that distribution. Finally, the fourth term, often referred to as the 'unobserved prices' effect, tells us about the impact of a widening or narrowing wage distribution; if the wage distribution is widening over time, then one might expect the gender wage gap to increase simply because women are concentrated in the lower part of the distribution.

Calculation of the last two terms in Eq. (6) involves first multiplying the coefficients of the male wage equations for each year to the corresponding female characteristics, and then subtracting the (log) wage thus estimated from the outturn in order to arrive at a hypothetical residual. The mean value of this hypothetical residual for year $x$ gives us a measure of $\Delta \theta_{x} \sigma_{\mathrm{m} x}$. The remaining term that is required is $\Delta \theta_{93} \sigma_{\mathrm{m} 00}$, and calculation of this is a little more complicated. First we consider the percentiles of the male residual wage distribution for 1993. Each female is then assigned a percentile number based on the position that her hypothetical residual would take in the actual distribution of male residuals in 1993. Applying this percentile to the 2000 distribution of male residuals gives an imputed female residual for the year 2000. The term $\Delta \theta_{93} \sigma_{\mathrm{m} 00}$ is then calculated as the mean of these residuals. Juhn et al. (1991) provide further detail on this method.

\section{Results}

We have regressed the earnings Eqs. (1)-(3) using data for male and female full-time workers, respectively, and also using pooled data for male and female workers. ${ }^{11}$ The estimated earnings equations are reported in Tables 1-3. The standard errors are adjusted using the Huber-White procedure. In general it is clear that the Mincerian specification works well, an exception being the equations for Russia, especially in 2000; this suggests that, owing to legacy issues dating back to the communist era, the human capital model may not adequately capture wage determination in this country, and if this is the case our estimates of 'unjustified' discrimination in Russia may be upwardly biased. The inverse u-shaped relationship between earnings and experience is observed here as in many other studies, with earnings peaking during the latter part of a worker's working life in Japan and the USA (1993). As shown in Table 4, the peak earnings year is earlier in the USA than in Japan. Also, the following are indicated: the years of experience at which earnings peak in Japan rose for males, but fell for the pooled sample of males and females between 1993 and 2000 . Schooling has a marked effect on earnings in all countries, though the effect is much smaller

\footnotetext{
${ }^{11}$ Earnings data in Japan 1993 are reported by categories in ISSP so that we have used mid-point values of each category as earnings data in order to make consistent with the earnings data in Japan 2000 because the latter data in the ISSP are reported as mid-point values of each category.
} 
Table 1

Estimations of Mincerian wage equations (Japan)

\begin{tabular}{|c|c|c|c|c|c|c|}
\hline \multirow[t]{2}{*}{ Variables } & \multicolumn{3}{|l|}{ Japan 1993} & \multicolumn{3}{|l|}{ Japan 2000} \\
\hline & Male & Female & Pooled & Male & Female & Pooled \\
\hline Experience & $0.068(4.965)[0.000]$ & $0.028(1.492)[0.138]$ & $0.047(4.077)[0.000]$ & $0.059(4.529)[0.000]$ & $0.082(3.620)[0.000]$ & $0.067(5.412)[0.000]$ \\
\hline $\begin{array}{l}\text { Experience } \\
\quad \text { squared }(\times 100)\end{array}$ & $-0.110(-3.925)[0.001]$ & $-0.043(-0.914)[0.362]$ & $-0.063(-2.458)[0.014]$ & $-0.088(-3.140)[0.002]$ & $-0.127(-2.366)[0.019]$ & $-0.099(-3.403)[0.001]$ \\
\hline Married & 0.189 (1877) [0.061] & $-0.315(-3.006)[0.003]$ & $0.074(1.014)[0.311]$ & $0.316(3.588)[0.000]$ & $-0.306(-2.466)[0.015]$ & 0.107 (1.518) [0.130] \\
\hline $\begin{array}{l}\text { Education } 1 \text { (High } \\
\text { school) }\end{array}$ & $0.338(4.751)[0.000]$ & $0.154(0.919)[0.360]$ & $0.363(4.313)[0.000]$ & $0.559(3.366)[0.001]$ & $0.706(3.080)[0.003]$ & $0.679(4.303)[0.000]$ \\
\hline $\begin{array}{l}\text { Education } 2 \text { (Junior } \\
\text { college) }\end{array}$ & $0.390(3.182)[0.002]$ & $0.331(1.741)[0.084]$ & $0.392(2.915)[0.004]$ & $0.613(3.090)[0.002]$ & 1.035 (3.870) [0.000] & $0.813(4.619)[0.000]$ \\
\hline $\begin{array}{l}\text { Education } 3 \\
\text { (University) }\end{array}$ & $0.616(7.962)[0.000]$ & $0.613(3.251)[0.001]$ & $0.866(9.420)[0.000]$ & $0.899(5.060)[0.000]$ & $1.448(4.891)[0.000]$ & $1.194(6.965)[0.000]$ \\
\hline Union member & $0.116(2.394)[0.017]$ & $0.532(5.494)[0.000]$ & $0.268(5.243)[0.000]$ & $0.179(3.071)[0.002]$ & $0.397(3.034)[0.003]$ & $0.293(4.848)[0.000]$ \\
\hline $\begin{array}{l}\text { Region } 1 \text { (Hokkaido } \\
\text { and Tohoku) }\end{array}$ & $-0.229(-2.414)[0.016]$ & $-0.353(-2.133)[0.035]$ & $-0.166(-1.698)[0.089]$ & $-0.223(-2.021)[0.044]$ & $-0.034(-0.191)[0.849]$ & $-0.207(-1.968)[0.050]$ \\
\hline Region 2 (Chubu) & $-0.063(-0.801)[0.424]$ & $-0.160(-0.971)[0.333]$ & $-0.016(-0.174)[0.862]$ & $0.122(1.605)[0.110]$ & $0.194(1.087)[0.279]$ & $0.080(0.849)[0.396]$ \\
\hline Region 3 (Kinki) & $-0.012(-0.146)[0.884]$ & $-0.040(-0.267)[0.790]$ & $0.009(0.099)[0.921]$ & $-0.046(-0.541)[0.589]$ & $-0.140(-0.758)[0.450]$ & $0.031(0.344)[0.731]$ \\
\hline $\begin{array}{l}\text { Region } 4 \text { (Chugoku } \\
\text { and Shikoku) }\end{array}$ & $-0.183(-2.320)[0.021]$ & $-0.311(-2.090)[0.038]$ & $-0.261(-2.646)[0.008]$ & $-0.265(-2.998)[0.003]$ & $-0.106(-0.446)[0.657]$ & $-0.148(-1.436)[0.152]$ \\
\hline Region 5 (Kyushu) & $-0.266(-2.828)[0.005]$ & $-0.033(-0.134)[0.893]$ & $-0.117(-1.133)[0.257]$ & $-0.411(-2.677)[0.008]$ & $0.193(1.019)[0.310]$ & $-0.158(-1.263)[0.207]$ \\
\hline Constant & $-0.687(-5.304)[0.000]$ & $-0.527(-2.691)[0.008]$ & $-0.774(-6.463)[0.000]$ & $-1.023(-5.836)[0.000]$ & $-1.735(-5.997)[0.000]$ & $-1.375(-8.086)[0.000]$ \\
\hline $\begin{array}{l}\text { Number of } \\
\text { observations }\end{array}$ & 344 & 166 & 510 & 255 & 148 & 403 \\
\hline$F$-value & 16.07 & 3.41 & 12.94 & 16.10 & 5.24 & 16.42 \\
\hline Prob $>F$ & {$[0.000]$} & {$[0.000]$} & {$[0.000]$} & {$[0.000]$} & {$[0.000]$} & {$[0.000]$} \\
\hline Adj $R$-squared & 0.345 & 0.149 & 0.220 & 0.416 & 0.257 & 0.315 \\
\hline
\end{tabular}

Note 1: The parentheses represent $t$-values and square brackets represent $P$-values. Note 2: Less than high school graduate is regarded as abase in educational attainment level of workers. Note 3 : Whole region of Kanto and Koshin-etsu is regarded as a base in regional dummy. 
Table 2

Estimations of Mincerian wage equations (Russia)

\begin{tabular}{|c|c|c|c|c|c|c|}
\hline \multirow[t]{2}{*}{ Variables } & \multicolumn{3}{|l|}{ Russia 1993} & \multicolumn{3}{|l|}{ Russia 2000} \\
\hline & Male & Female & Pooled & Male & Female & Pooled \\
\hline Experience & 0.024 (1.972) [0.049] & $0.011(1.037)[0.300]$ & $0.013(1.587)[0.113]$ & $-0.015(-0.991)[0.322]$ & $0.022(1.105)[0.270]$ & $-0.007(-0.529)[0.597]$ \\
\hline Experience squared $(\times 100)$ & $-0.061(-2.256)[0.025]$ & $-0.035(-1.328)[0.185]$ & $-0.039(-2.071)[0.038]$ & $0.019(0.564)[0.573]$ & $-0.029(-0.584)[0.560]$ & $0.021(0.750)[0.453]$ \\
\hline Married & 0.137 (1.652) [0.099] & $0.166(2.715)[0.007]$ & $0.222(4.380)[0.000]$ & $0.180(1.653)[0.100]$ & $-0.217(-2.034)[0.043]$ & $0.036(0.457)[0.647]$ \\
\hline $\begin{array}{l}\text { Education } 1 \text { (Incomplete } \\
\text { secondary level) }\end{array}$ & $0.041(0.383)[0.702]$ & $-0.058(-0.495)[0.621]$ & $-0.048(-0.573)[0.566]$ & $-0.267(-1.166)[0.245]$ & $0.083(0.305)[0.761]$ & $-0.065(-0.366)[0.714]$ \\
\hline $\begin{array}{l}\text { Education } 2 \text { (Secondary } \\
\text { completed) }\end{array}$ & $0.057(0.491)[0.624]$ & $0.146(1.415)[0.158]$ & $-0.009(-0.116)[0.908]$ & $0.343(2.005)[0.046]$ & $-0.033(-0.165)[0.869]$ & $0.263(2.000)[0.046]$ \\
\hline $\begin{array}{l}\text { Education } 3 \text { (Incomplete } \\
\text { university level) }\end{array}$ & 0.249 (1.292) [0.197] & $0.392(2.162)[0.031]$ & $0.285(2.102)[0.036]$ & $0.310(1.785)[0.075]$ & $0.223(1.249)[0.213]$ & $0.263(2.091)[0.037]$ \\
\hline $\begin{array}{l}\text { Education } 4 \text { (University } \\
\text { completed) }\end{array}$ & 0.243 (1.914) [0.056] & $0.416(3.786)[0.000]$ & $0.274(3.117)[0.002]$ & $0.574(3.083)[0.002]$ & 0.539 (2.712) [0.007] & $0.666(4.966)[0.000]$ \\
\hline Union member & $-0.013(-0.149)[0.882]$ & $-0.046(-0.529)[0.597]$ & $-0.064(-1.019)[0.308]$ & $0.050(0.542)[0.588]$ & $-0.160(-1.585)[0.114]$ & $-0.109(-1.538)[0.124]$ \\
\hline Region 1 (North-West) & $-0.469(-3.476)[0.001]$ & $-0.185(-1.420)[0.156]$ & $-0.322(-3.346)[0.001]$ & $-0.224(-1.383)[0.168]$ & $0.016(0.094)[0.925]$ & $-0.155(-1.143)[0.253]$ \\
\hline Region 2 (North Caucasus) & $-0.396(-3.247)[0.001]$ & $-0.300(-2.590)[0.010]$ & $-0.310(-3.564)[0.000]$ & $-0.897(-4.323)[0.000]$ & $-0.316(-1.680)[0.094]$ & $-0.654(-4.418)[0.000]$ \\
\hline Region 3 (Volga-Vyatka) & $-0.555(-4.433)[0.000]$ & $-0.273(-2.038)[0.042]$ & $-0.394(-4.124)[0.000]$ & $-0.734(-4.065)[0.000]$ & $-0.095(-0.505)[0.614]$ & $-0.465(-3.636)[0.000]$ \\
\hline Region 4 (Volga) & $-0.517(-4.935)[0.006]$ & $-0.537(-5.425)[0.000]$ & $-0.506(-6.611)[0.000]$ & $-0.510(-4.169)[0.000]$ & $-0.011(-0.062)[0.951]$ & $-0.247(-2.411)[0.016]$ \\
\hline Region 5 (Urals) & $-0.191(-1.631)[0.104]$ & $-0.182(-1.638)[0.102]$ & $-0.220(-2.566)[0.010]$ & $-0.552(-4.371)[0.000]$ & $-0.350(-2.181)[0.030]$ & $-0.408(-3.792)[0.000]$ \\
\hline $\begin{array}{l}\text { Region } 6 \text { (Central black } \\
\text { earth) }\end{array}$ & $-0.262(-2.209)[0.028]$ & $-0.231(-1.799)[0.073]$ & $-0.201(-2.260)[0.024]$ & $-0.689(-3.391)[0.001]$ & $-0.368(-1.850)[0.066]$ & $-0.468(-2.950)[0.003]$ \\
\hline $\begin{array}{l}\text { Region } 7 \text { (West Siberia, } \\
\text { East Siberia and Far } \\
\text { East) }\end{array}$ & $-0.383(-3.188)[0.002]$ & $-0.297(-2.947)[0.003]$ & $-0.352(-4.356)[0.000]$ & $-0.347(-2.537)[0.012]$ & $-0.041(-0.256)[0.798]$ & $-0.225(-1.991)[0.046]$ \\
\hline Constant & $5.429(33.462)[0.000]$ & 5.087 (32.397) [0.000] & $5.328(45.334)[0.000]$ & $2.242(10.837)[0.000]$ & $1.489(5.761)[0.000]$ & 1.906 (11.414) [0.000] \\
\hline Number of observations & 396 & 447 & 843 & 288 & 235 & 523 \\
\hline$F$-value & 4.45 & 5.59 & 8.79 & 5.65 & 2.11 & 5.12 \\
\hline Prob $>F$ & {$[0.000]$} & {$[0.000]$} & {$[0.000]$} & {$[0.000]$} & {$[0.010]$} & {$[0.000]$} \\
\hline Adj $R$-squared & 0.116 & 0.134 & 0.123 & 0.195 & 0.066 & 0.106 \\
\hline
\end{tabular}

Note 1: The parentheses represent $t$-values and the square bracket represents $P$-values. Note 2: Incomplete primary and primary completed are regarded as a base in educational attainment level of workers. Note 3: Whole region of Moscow and Central is regarded as a base in regional dummy. 
Table 3

Estimations of Mincerian wage equations (the United States of America)

\begin{tabular}{|c|c|c|c|c|c|c|}
\hline \multirow[t]{2}{*}{ Variables } & \multicolumn{3}{|l|}{ USA 1993} & \multicolumn{3}{|l|}{ USA 2000} \\
\hline & Male & Female & Pooled & Male & Female & Pooled \\
\hline Experience & $0.077(4.828)[0.000]$ & $0.058(4.304)[0.000]$ & $0.069(6.535)[0.000]$ & $0.031(1.599)[0.111]$ & $0.024(1.231)[0.220]$ & $0.031(2.306)[0.021]$ \\
\hline $\begin{array}{l}\text { Experience } \\
\quad \text { squared }(\times 100)\end{array}$ & $-0.143(-3.399)[0.001]$ & $-0.105(-3.328)[0.001]$ & $-0.127(-4.758)[0.000]$ & $-0.039(-0.894)[0.372]$ & $-0.033(-0.737)[0.462]$ & $-0.048(-1.527)[0.127]$ \\
\hline Married & $0.182(2.522)[0.012]$ & $-0.043(-0.633)[0.528]$ & $0.118(2.386)[0.017]$ & $0.204(1.833)[0.068]$ & $0.039(0.408)[0.683]$ & $0.177(2.394)[0.017]$ \\
\hline $\begin{array}{l}\text { Education } 1 \text { (High } \\
\text { school) }\end{array}$ & $0.320(2.199)$ [0.029] & $0.287(1.632)$ [0.104] & $0.238(2.114)[0.035]$ & $0.390(1.870)[0.062]$ & $0.594(1.983)[0.048]$ & $0.420(2.388)[0.017]$ \\
\hline $\begin{array}{l}\text { Education } 2 \\
\quad \text { (Junior college) }\end{array}$ & $0.429(2.597)[0.010]$ & $0.539(2.574)[0.011]$ & $0.422(3.247)[0.001]$ & $0.387(1.416)[0.158]$ & $1.067(3.417)[0.001]$ & $0.648(3.215)[0.001]$ \\
\hline $\begin{array}{l}\text { Education } 3 \\
\quad \text { (Bachelor degree) }\end{array}$ & $0.779(5.083)[0.000]$ & $0.648(3.437)[0.001]$ & $0.653(5.414)[0.000]$ & $0.648(2.871)[0.004]$ & $1.138(3.740)[0.000]$ & $0.812(4.378)[0.000]$ \\
\hline $\begin{array}{l}\text { Education } 4 \text { (Graduate } \\
\text { school) }\end{array}$ & $0.977(5.752)[0.000]$ & $1.070(5.349)[0.000]$ & $0.977(7.561)[0.000]$ & $1.171(4.121)[0.000]$ & $1.448(3.279)[0.001]$ & $1.299(5.313)[0.000]$ \\
\hline Union member & $0.414(3.812)[0.000]$ & $0.100(1.034)[0.302]$ & $0.296(3.669)[0.000]$ & $0.147(1.287)$ [0.199] & $0.091(0.687)$ [0.493] & 0.109 (1.305) [0.192] \\
\hline $\begin{array}{l}\text { Region } 1 \text { (New } \\
\text { England) }\end{array}$ & $0.294(1.799)$ [0.073] & $0.111(0.406)$ [0.685] & $0.250(1.693)[0.090]$ & $0.068(0.400)$ [0.689] & $0.067(0.249)$ [0.804] & $0.035(0.214)[0.831]$ \\
\hline $\begin{array}{l}\text { Region } 2 \text { (Middle } \\
\text { Atlantic) }\end{array}$ & $0.079(0.683)[0.495]$ & $0.123(0.950)[0.343]$ & 0.089 (1.008) [0.314] & $0.278(1.221)[0.223]$ & $0.292(1.710)[0.088]$ & $0.262(1.827)[0.068]$ \\
\hline $\begin{array}{l}\text { Region } 3 \text { (East North } \\
\text { Central) }\end{array}$ & $-0.064(-0.526)[0.599]$ & $-0.012(-0.095)[0.924]$ & $-0.038(-0.432)[0.666]$ & $0.045(0.261)[0.794]$ & $0.290(1.727)[0.085]$ & $0.177(1.426)[0.154]$ \\
\hline $\begin{array}{l}\text { Region } 4 \text { (West } \\
\text { North Central) }\end{array}$ & $-0.053(-0.419)[0.676]$ & $-0.310(-1.879)[0.061]$ & $-0.172(-1.511)[0.131]$ & $-0.099(-0.634)[0.527]$ & $0.068(0.272)[0.786]$ & $-0.021(-0.141)[0.888]$ \\
\hline $\begin{array}{l}\text { Region } 5 \text { (East } \\
\quad \text { South Central) }\end{array}$ & $-0.232(-1.675)[0.095]$ & $-0.318(-1.936)[0.054]$ & $-0.303(-2.778)[0.006]$ & $-0.068(-0.383)[0.702]$ & $-0.099(-0.498)[0.619]$ & $-0.126(-0.916)[0.360]$ \\
\hline $\begin{array}{l}\text { Region } 6 \text { (West South } \\
\text { Central) }\end{array}$ & $-0.153(-1.185)[0.237]$ & $-0.164(-1.317)[0.189]$ & $-0.168(-1.818)[0.069]$ & $-0.054(-0.313)[0.755]$ & $0.176(1.043)[0.298]$ & $0.047(0.382)$ [0.703] \\
\hline Region 7 (Mountain) & $-0.373(-2.780)[0.006]$ & $-0.223(-1.543)[0.124]$ & $-0.328(-3.235)[0.001]$ & $-0.008(-0.036)[0.971]$ & $0.188(0.863)$ [0.389] & $0.076(0.480)[0.631]$ \\
\hline Region 8 (Pacific) & $0.020(0.164)[0.870]$ & $0.111(0.912)[0.362]$ & $0.051(0.571)[0.568]$ & $0.253(1.204)[0.229]$ & $0.262(1.279)[0.202]$ & $0.214(1.480)$ [0.139] \\
\hline Constant & $0.862(4.858)[0.000]$ & $0.974(4.493)[0.000]$ & $0.963(6.408)[0.000]$ & $1.575(5.912)[0.000]$ & $1.027(3.203)[0.002]$ & $1.353(6.564)[0.000]$ \\
\hline Number of observations & 373 & 315 & 688 & 324 & 287 & 611 \\
\hline$F$-value & 11.10 & 6.36 & 16.71 & 2.94 & 4.19 & 6.28 \\
\hline Prob $>F$ & {$[0.000]$} & {$[0.000]$} & {$[0.000]$} & {$[0.000]$} & {$[0.000]$} & {$[0.000]$} \\
\hline Adj $R$-squared & 0.303 & 0.215 & 0.268 & 0.087 & 0.151 & 0.122 \\
\hline
\end{tabular}

Note 1: The parentheses represent $t$-values and the square brackets represent $P$-values. Note 2: Less than high school graduate is regarded as a base in educational attainment level of workers. Note 3:

South atlantic region is regarded as a base in regional dummy. 
Table 4

Experience years in which earnings are peaked (years)

\begin{tabular}{lccc}
\hline & Male & Female & Pooled data \\
\hline $\begin{array}{l}\text { Japan } \\
1993\end{array}$ & 30.9 & & 37.3 \\
2000 & 33.5 & 32.3 & 33.8 \\
Russia & & & \\
1993 & 19.6 & & 27.2 \\
2000 & & 27.6 & \\
USA & 26.9 & & \\
1993 & & & \\
2000 & 2600 &
\end{tabular}

Note: The values are not calculated when the coefficients are insignificant.

in Russia than elsewhere. ${ }^{12}$ This might be a legacy of the former system in which wage structures were relatively compressed. In 1993, for example, male workers who had completed secondary education earned a premium of a little over 30 percent in Japan and the USA, while those whose highest qualification was at higher education level earned a premium of over 60 percent. The rate of return to education, as measured by the significant coefficients on the schooling variables, has been increasing somewhat for both genders in each country over the study period. The impact of skill biased technical change is often cited as an explanation for this (Machin, 2004). The rise in the rate of return to education in Japan has been particularly pronounced for women. The low rates of return to education for Russian workers are also noteworthy, and the estimated coefficients are statistically insignificant except university graduates.

In common with many earlier studies, we find that marriage adds to the earnings of males (though Russian women have mixed results in 1993 and 2000), and in some cases (Japan) it diminishes the earnings of females. Union membership has the anticipated effect of raising wages in Japan and for males in the USA; indeed for Japanese women the union effect is huge, and probably captures in part the impact of occupational choice. In Russia, on the other hand, union membership has no impact on earnings. This is likely due to some ambiguity in the definition and role of trade unions in that country; while independent unions have developed during the transition, labour organisations are still dominated by unions that originated in the Soviet era and which primarily acted in the interests of the state rather than of workers (Ashwin and Clarke, 2002).

The regional effects are reported in full in the tables because they provide particularly interesting information. In Japan, we have two different results about region dummies, that is, region 1 (Hokkaido and Tohoku), region 4 (Chugoku and Shikoku) and region 5 (Kyushu) have statistically significant and negative coefficients in most cases but other regions (Chubu and Kinki) have insignificant coefficients so that these regions have no different effects on earnings from ones in the base region (Kanto and Koshin-etsu). Chubu and Kinki include large cities, Nagoya and Osaka, like Kanto and Koshin-etsu, which includes Tokyo. Therefore, the estimation results show quite clear regional differences in Japan.

\footnotetext{
${ }^{12}$ Some recent studies have instrumented for schooling using measures such as smoking behaviour (Evans and Montgomery, 1994; Johnes, 2002) as proxies of attitudes to risk. Unfortunately no such data are routinely available in the ISSP.
} 
The regional effects in the USA and Russia have shown completely different pattern, although both of them have big land. In the USA, most coefficients of regional dummies have shown statistically insignificant, while regional variables are important determinants to earnings in Russia. Since most coefficients of regional variables became insignificant in the USA, we can say that there are no regional differences on earnings of American male and female workers. The exceptional cases are that female workers in some Central regions and male workers in the Mountain region earned less than the workers in the base region (South Atlantic region), respectively and male workers in the New England earned more than the male workers in South Atlantic region in 1993. But even these effects have disappeared in 2000 among male and female workers, respectively.

The regional effects are most interesting in the case of Russia. In the case of male workers in 1993, all regional dummy variables except that for the Urals region are statistically significant. Hence, male workers in the North-West, North Caucasus, Volga-Vyatka, Volga and Central Black Earth, and Siberia and Far East regions earned less than the male workers in the base region (Moscow and Central regions). The main feature of the regional effects in 2000 are that male and female workers in the Urals region have earned less significantly when compared with the base region, and that the coefficients of female workers in most regions except the Urals became insignificant. The differential impact of reform on the various Russian regions has been well documented recently by Berkowitz and DeJong (2003). Other accounts are provided by Hanson (2001) and by Hanson and Bradshaw (2000).

The observations made above are based on the best estimates of coefficients in the years 1993 and 2000. Nevertheless, it may be the case that while coefficients differ across years, they do not do so significantly. In order to check for this, we have run a pooled regression for each country and conducted $F$ tests to establish whether this pooling is supported by the data. The results indicate that the wage function indeed changed significantly in the case of the USA and Russia $\left(F_{17,1265}=5.71\right.$ and $F_{16,1334}=319.08$, respectively $)$, but not in the case of Japan $\left(F_{13,887}=0.94\right)$.

We turn now to consider the results that are obtained when decomposing the wage differential between men and women using the Oaxaca-Ransom approach outlined earlier. These are summarised in Table 5.

The first thing to observe in these results is that the total wage differential is much higher in Japan than in either Russia or the USA. It is more than twice of that in Russia and the USA in 1993, although the Japanese wage differential in 2000 is narrowed in comparison with the earlier year. The individual components of the differential are likewise higher in Japan than in the other two countries. Particularly marked in Japan is the big weight assigned to female disadvantage effects, that is, about one-half of the gender wage differential is explained by female disadvantage due to price effects.

Second, the characteristics effects are relatively a less important factor in both years as an explanation of the gender wage differential in every country considered here. In Russia especially, it has only a minor impact on the total wage differential. However, by 2000, in Japan the proportion of the total wage gap accounted for by this effect had increased, and the weights associated with it exceed slightly those attached to the male advantage effects.

Third, in Russia and the USA, male advantage and female disadvantage have nearly same weights in the total wage differential. In Russia more than 90 percent of the total wage differential is explained by male advantage and female disadvantage factors and in the USA more than 80 percent of it is explained by male advantage and female disadvantage factors. In Japan, on the other hand, the female disadvantage factor really dominates.

Fourth, Japan and other two countries have also shown quite different results when we consider changes in the gender wage differential between 1993 and 2000. In Japan the total wage 
Table 5

Oaxaca-Ransom decompositions of the gender wage differential (full-time workers)

\begin{tabular}{|c|c|c|c|}
\hline & 1993 & 2000 & Changes \\
\hline \multicolumn{4}{|l|}{ Japan } \\
\hline $\begin{array}{l}\text { Estimates of gender wage differential (in logarithm): } \\
\qquad \ln \left(G_{\mathrm{mf}}+1\right)\end{array}$ & $0.7554(100.0 \%)$ & $0.5890(100.0 \%)$ & -0.1664 \\
\hline Male advantage due to price effects: $\bar{X}_{\mathrm{m}}^{\prime}\left(\hat{\beta}_{\mathrm{m}}-\beta^{*}\right)$ & $0.1910(25.3 \%)$ & $0.1579(26.8 \%)$ & -0.0331 \\
\hline Female disadvantage due to price effects: $\bar{X}_{\mathrm{f}}^{\prime}\left(\beta^{*}-\hat{\beta}_{\mathrm{f}}\right)$ & $0.3956(52.4 \%)$ & $0.2721(46.2 \%)$ & -0.1235 \\
\hline The characteristics effects: $\left(\bar{X}_{\mathrm{m}}-\bar{X}_{\mathrm{f}}\right)^{\prime} \beta^{*}$ & $0.1688(22.3 \%)$ & $0.1590(27.0 \%)$ & -0.0098 \\
\hline \multicolumn{4}{|l|}{ Russia } \\
\hline $\begin{array}{l}\text { Estimates of gender wage differential (in logarithm): } \\
\qquad \ln \left(G_{\mathrm{mf}}+1\right)\end{array}$ & $0.3682(100.0 \%)$ & $0.3881(100.0 \%)$ & 0.0199 \\
\hline Male advantage due to price effects: $\bar{X}_{\mathrm{m}}^{\prime}\left(\hat{\beta}_{\mathrm{m}}-\beta^{*}\right)$ & $0.1763(47.9 \%)$ & $0.1693(43.6 \%)$ & -0.0070 \\
\hline Female disadvantage due to price effects: $\bar{X}_{\mathrm{f}}^{\prime}\left(\beta^{*}-\hat{\beta}_{\mathrm{f}}\right)$ & $0.1721(46.7 \%)$ & $0.2011(51.8 \%)$ & 0.0290 \\
\hline The characteristics effects: $\left(\bar{X}_{\mathrm{m}}-\bar{X}_{\mathrm{f}}\right)^{\prime} \beta^{*}$ & $0.0198(5.4 \%)$ & $0.0177(4.6 \%)$ & -0.0021 \\
\hline \multicolumn{4}{|l|}{ United States of America } \\
\hline $\begin{array}{l}\text { Estimates of gender wage differential (in logarithm): } \\
\qquad \ln \left(G_{\mathrm{mf}}+1\right)\end{array}$ & $0.2852(100.0 \%)$ & $0.3597(100.0 \%)$ & 0.0745 \\
\hline Male advantage due to price effects: $\bar{X}_{\mathrm{m}}^{\prime}\left(\hat{\beta}_{\mathrm{m}}-\beta^{*}\right)$ & $0.1067(37.4 \%)$ & $0.1505(41.8 \%)$ & 0.0438 \\
\hline Female disadvantage due to price effects: $\bar{X}_{\mathrm{f}}^{\prime}\left(\beta^{*}-\hat{\beta}_{\mathrm{f}}\right)$ & $0.1263(44.3 \%)$ & $0.1699(47.2 \%)$ & 0.0436 \\
\hline The characteristics effects: $\left(\bar{X}_{\mathrm{m}}-\bar{X}_{\mathrm{f}}\right)^{\prime} \beta^{*}$ & $0.0522(18.3 \%)$ & $0.0393(11.0 \%)$ & -0.0129 \\
\hline
\end{tabular}

differential between men and women has reduced by more than 25 percentage points between these years, but it increased by 2 percentage points and 7 percentage points in Russia and the USA respectively from 1993 to 2000 . In Japan, while the male advantage factor and the characteristics factor have both decreased slightly, female disadvantage factor has decreased considerably so that the total wage differential between men and women has reduced. Japan's Gender Equal Employment Opportunity Law was enacted in 1985 and implemented in the following year, and it was amended in 1997. One of the reasons why Japan has shown the gender wage differential reduced may be that the implementation of the Law had some effect. On the other hand, in Russia and the USA, the increased differential between male and female earnings is explained by a rise in female disadvantage component of the differential (in Russia) and by rises in male advantage and female disadvantage components (in the USA) of the differential. That this should be so is perhaps unsurprising in view of the widening income distributions that have been observed in these countries. In the USA, the increased distribution of earnings has often been linked to downward pressure on wages at the bottom end of the labour market that has resulted from the increase in global competition (see, for example, Freeman, 1995). In Russia, on the other hand, liberalisation of the labour market has led to a very substantial widening of the income distribution (see Bogomolova and Tapilina, 1999). In both cases, this likely resulted in changes in the returns to characteristics that had a differential impact across the genders.

Results obtained for the Juhn et al. decomposition are reported in Table 6 and we can see that these results confirm the trends of changes in gender wage differential shown by Table 5. These indicate that recent changes in Japan are qualitatively different from those in Russia and the USA. In the latter two countries, the unobserved price effect has dominated (in line with the vivid 'swimming upstream' metaphor used by Blau and Kahn, 1997), and the gender gap appears to have widened during the 1990s. In Japan, by way of contrast, the unobserved prices term has contributed to a narrowing of the gender wage differential. This is perhaps surprising in view of 
Table 6

Juhn et al. decompositions

\begin{tabular}{lrrr}
\hline & Japan & Russia & USA \\
\hline Observed characteristics & 0.020 & -0.055 & 0.025 \\
Observed prices & -0.046 & 0.058 & -0.001 \\
Gap & 0.112 & 0.039 & 0.057 \\
Unobserved prices & 0.079 & -0.129 & -0.161 \\
Total differential & 0.166 & -0.086 & -0.075 \\
\hline
\end{tabular}

Note: Columns do not sum to the total differential perfectly owing to rounding at various stages of the calculation. The differential for Russia differs from that reported in Table 5 because of not using the weighted method which was used to derive the results shown by Table 5. Although this table and Table 5 are the results of using the weighted variables and nonweighted variables, respectively, the trend of changes in gender wage differential in Russia is similar in both methods.

Table 7

Wage distributions in Japan, 1993 and 2000

\begin{tabular}{lll}
\hline Percentage with wage below (\%) & In 1993 (proportion of mean wage) & In 2000 (proportion of mean wage) \\
\hline 10 & 0.34 & 0.30 \\
20 & 0.46 & 0.41 \\
30 & 0.61 & 0.57 \\
40 & 0.71 & 0.69 \\
50 & 0.84 & 0.90 \\
60 & 0.97 & 1.02 \\
70 & 1.18 & 1.24 \\
80 & 1.42 & 1.48 \\
90 & 1.92 & 1.93 \\
\hline
\end{tabular}

Source: Authors' calculations from ISSP; pooled sample of men and women.

the fact that the overall income distribution in Japan widened during the 1990s (Ostrom, 1999) but in fact the rising Gini coefficient over that period masks the fact that the distribution was widening over some parts but narrowing over others ${ }^{13}$; this is evidenced by Table 7 , where it is easily seen that the distribution widened at the extremes, but narrowed at the middle. Thus many women just below the middle of the wage distribution in 1993 will have benefited from the change in the wage distribution in Japan over the 1990s, and hence this explains why the unobserved prices effect is positive. Nevertheless, the main factor contributing to the narrowing of wage differentials in Japan has been the gap effect. Women in Japan have been moving rapidly upward through the distribution. These observations make the recent experience of Japan qualitatively different from that of both the USA and Russia, an issue which we think is worthy of further research.

\section{Conclusion}

The present study has highlighted some surprising comparisons across three countries that are very different in terms of their labour market structures. The wage differential between men and

\footnotetext{
${ }^{13}$ This serves to highlight a major advantage of the Juhn et al. approach, namely that it compares the experience of men and women across the whole distribution.
} 
women, and the components of that differential, have proved to be remarkably similar in Russia and the USA. This is so in both 1993 and 2000, despite the rapid restructuring that took place in the former country over this time interval.

In Japan, on the other hand, gender wage differentials are much more pronounced, although the wage differential between men and women has reduced by more than 20 percent between 1993 and 2000. They are due to both characteristics and price effects. It is especially remarkable that the discrimination against female workers is main component of the gender wage differentials, although it should be borne in mind that the data that have been available in this study are necessarily limited. Previous researches of the Japanese gender wage differentials have shown, by way of contrast, that the characteristics effects were the main factor to explain wage differentials. Therefore, the magnitude of these effects in Japan serves to highlight the value of conducting analyses of discrimination with microdata. This argument applies with additional force once it is recognised that the experience of Japan over the last 15 years or so is qualitiatively different from that of other countries in this study.

It is appropriate that we should end this paper with a discussion of some of its limitations. The ISSP data is limited in that the sample size for each country is fairly modest. It is not primarily a labour force survey. And it is not a panel data set. But, even though this data set has such limitations, by using the same microdata set that is in the public domain, the present study has shown that experience of discrimination in Japan differs from that of some other (well studied) countries. The call for future research that traditionally concludes research papers would seem to be especially apposite here.

\section{References}

Ashwin, S., Clarke, S., 2002. Russian Trade Unions and Industrial Relations in Transition. Palgrave, Basingstoke.

Becker, G.S., 1957. The Economics of Discrimination. University of Chicago Press, Chicago.

Becker, G.S., 1964. Human Capital. Columbia University Press, New York.

Berger, M.C., Earle, J.S., Sabirianova, K.Z., 2001. Worker training in a restructuring economy: evidence from the Russian transition. In: Polachek, S. (Ed.), Research in Labor Economics, vol. 20. pp. 159-190.

Berkowitz, D., DeJong, D.N., 2003. Policy reform and growth in post-Soviet Russia. European Economic Review 47, 337-352.

Bertola, G., Blau, F.D., Kahn, L.M., 2003. Labor Market Institutions and Demographic Employment Patterns, Mimeo. European University Institute.

Blanchflower, D.G., Freeman, R., 1997. The attitudinal legacy of communist labor relations. Industrial and Labor Relations Review 50, 438-459.

Blau, F., Ferber, M.A., 1987. Discrimination: empirical evidence from the United States. American Economic Association Papers and Proceedings, vol. 77. pp. 316-320.

Blau, F.D., Kahn, L.M., 1995. The gender earnings gap: some international evidence. In: Freeman, R.B., Katz, L.F. (Eds.), Differences and Changes in Wage Structure, vol. 111. The University of Chicago Press, Chicago, pp. 105143.

Blau, F., Kahn, L., 1996. Wage structure and gender earnings differentials: an international comparison. Economica 63, S29-S62.

Blau, F., Kahn, L., 1997. Swimming upstream: trends in the gender income differential in the 1980s. Journal of Labor Economics 15, 1-42.

Blau, F., Kahn, L., 2003. Understanding international differences in the gender pay gap. Journal of Labor Economics 21 , $106-144$.

Blinder, A., 1973. Wage discrimination: reduced form and structural estimates. Journal of Human Resources 8, 436-455.

Bogomolova, T., Tapilina, V., 1999. Income mobility in Russia in the mid-1990s, EERC Working Paper 99/11, available at http://www.eerc.ru/publications/wp/.

Booth, A., Francesconi, M., Frank, J., 2003. A sticky floors model of promotion, pay and gender. European Economic Review 47, 295-322. 
Evans, W.N., Montgomery, E., 1994. Education and health: where there's smoke there's an instrument, NBER Working Paper 4949, Cambridge, MA.

Freeman, R., 1995. Are your wages set in Beijing? Journal of Economic Perspectives 9 (3), 15-32.

Glinskaya, E., Mroz, T., 2000. The gender gap in wages in Russia from 1992 to 1995. Journal of Population Economics 13, 353-386.

Gordon, R.J., 1982. Why U.S. wage and employment behaviour differs from that in Britain and Japan. Economic Journal 92, 13-44.

Hanson, P., 2001. Regional income differences. In: Granville, B., Oppenheimer, P. (Eds.), Russia's Post-Communist Economy. Oxford University Press, Oxford.

Hanson, P., Bradshaw, M., 2000. Regional Economic Change in Russia. Edward Elgar, Cheltenham.

Hashimoto, M., 1990. The Japanese Labor Market in a Comparative Perspective with the United States: A TransactionCost Interpretation. W.E. Upjohn Institute for Employment Research, Kalamazoo, Michigan.

Heckman, J.J., 1979. Sample selection bias as a specification error. Econometrica 47, 153-161.

International Labour Office (ILO), 1992. World Labour Report 1992, Geneva.

Johnes, G., 1998. Human capital versus sorting: new data and a new test. Applied Economics Letters 5, $665-667$.

Johnes, G., 2002. A Tajik story: the labour market following war and transition. Economic Systems 26, 17-30.

Jovanovic, B., Lokshin, M.M., 2004. Wage differentials between the state and private sectors in Moscow. Review of Income and Wealth 50, 107-123.

Juhn, C., Murphy, K.M., Pierce, B., 1991. Accounting for the slowdown in black-white wage convergence. In: Kosters, M. (Ed.), Workers and their Wages. AEI Press, Washington.

Juhn, C., Murphy, K.M., Pierce, B., 1993. Wage inequality and the rise in returns to skill. Journal of Political Economy $101,410-442$.

Lazear, E.P., Rosen, S., 1990. Male-female wage differentials in job ladders. Journal of Labor Economics 8, S106-S123.

Machin, S., 2004. Skill-biased technical change. In: Johnes, G., Johnes, J. (Eds.), International Handbook on the Economics of Education. Edward Elgar, Cheltenham.

Mincer S J., 1974. Schooling, Experience and Earnings. National Bureau of Economic Research, New York.

Mincer, J., 1985. Intercountry comparisons of labor force trends and of related developments: an overview. Journal of Labor Economics 3 (1) Part 2, S1-S32.

Newell, A., Reilly, B., 1996. The gender wage gap in Russia: some empirical evidence. Labour Economics 3, 337-356.

Newell, A., Reilly, B., 1999. Rates of return to educational qualifications in the transitional economies. Education Economics 7, 67-84.

Newell, A., Reilly, B., 2001. The gender pay gap in the transition from communism: some empirical evidence, IZA Discussion Paper 268.

Oaxaca, R.L., 1973. Male-female wage differentials in urban labor markets. International Economic Review 14, 693-709.

Oaxaca, R.L., Ransom, M.R., 1994. On discrimination and the decomposition of wage differentials. Journal of Econometrics 61, 5-21.

Oglobin, C.G., 1999. The gender earnings differential in the Russian transition economy. Industrial and Labor Relations Review 52, 602-627.

Ostrom, D., 1999. Rich and poor in Japan: how wide is the gap? Japan Economic Institute Report, 37, available at http:// www.jei.org/Archive/JEIR99/9937f.html.

Polachek, S.W., Kim, M.-K., 1994. Panel estimates of the gender earnings gap. Journal of Econometrics 61, $23-42$.

Puhani, P., 2000. The Heckman correction for sample selection and its critique: a short survey. Journal of Economic Surveys 14, 53-68.

Schultz, T., 1961. Investment in human capital. American Economic Review 51, 1-17.

Tanaka, Y., 2002. A reconsideration of male-female wage differentials in Japan: the effects of discrimination and "job expectancy". JCER Economic Journal 45, 176-200 (in Japanese).

Yashiro, N., 1980. On the factors of wage discrimination between male and female its rationality and policy. JCER Economic Journal 9, 17-31 (in Japanese). 